FREITAS, MSM; GONÇALVES, YS; LIMA, TC; SANTOS, PC; PEÇANHA, DA; VIEIRA, ME; CARVALHO, AJC; VIEIRA, IJC. 2020. PotasSium sources and doses in coriander fruit production and essential oil content. Horticultura Brasileira 38: 268-273. http://dx.doi.org/10.1590/S0102-053620200305

\title{
Potassium sources and doses in coriander fruit production and essential oil content
}

\author{
Marta Simone M Freitas ${ }^{1} \mathbb{D}$; Ygor de S Gonçalves ${ }^{1} \mathbb{D}$; Thaísa C Lima ${ }^{1} \mathbb{D}$; Paulo Cesar dos Santos ${ }^{1} \mathbb{D}$; Diego \\ A Peçanha ${ }^{1} \mathbb{D}$; Marlene E Vieira ${ }^{1} \mathbb{D} ;$ Almy JC de Carvalho ${ }^{1} \mathbb{D}$; Ivo José C Vieira ${ }^{1} \mathbb{D}$
}

${ }^{1}$ Universidade Estadual do Norte Fluminense Darcy Ribeiro (UENF), Campos dos Goytacazes-RJ, Brasil; martasimonefreitas@hotmail.com; ygor.agrouenf@gmail.com; thaisacapato@hotmail.com; pcsantos18@hotmail.com; diegopecanha333@yahoo.com.br; marlenevieira_evan@ hotmail.com; almy@fruticultura.org; curcinovieira@gmail.com

\begin{abstract}
Potassium $(\mathrm{K})$ is one of the most required agricultural crop macronutrients, with potassium chloride being the most applied source. However, this fertilizer is not recommended for several crops due to its high chlorine content, promoting final product quality losses, thus being replaced by potassium sulphate. The aim of the present study was to evaluate the production and macronutrient, essential oil and linalool contents of coriander fruits submitted to different potassium sources and doses. The research was performed in a greenhouse, in plastic $46 \mathrm{~kg}$ boxes applying a mixture of soil and sand as substrate. The experimental design was of randomized blocks, applying a $2 \times 4$ factorial arrangement, with two potassium sources (potassium chloride and sulphate) at four doses $(50,100$, 150 and $200 \mathrm{mg}$ of $\mathrm{K} / \mathrm{kg}$ substrate), performing four replicates. The highest fruit yields, and phosphorus and sulfur fruit contents were verified in plants fertilized with $\mathrm{K}_{2} \mathrm{SO}_{4}$. The application of increasing potassium doses, regardless of the source, resulted in increased $\mathrm{K}$ and decreased $\mathrm{Ca}$ contents and did not affect $\mathrm{N}$ and $\mathrm{Mg}$ fruit levels in the fruits. The highest essential oil concentration in fruits $(0.15 \mathrm{~g})$ and linalool in essential oils $(0.42 \mathrm{mg})$ were verified when 153.8 and $131.3 \mathrm{mg}$ of $\mathrm{K} / \mathrm{kg}$ substrate using $\mathrm{K}_{2} \mathrm{SO}_{4}$ were applied, respectively.
\end{abstract}

Keywords: Coriandrum sativum, nutrients, secondary metabolism, linalool.

\section{RESUMO}

Fontes e doses de potássio na produção de frutos e teor de óleos essenciais de coentro

O potássio $(\mathrm{K})$ é um dos macronutrientes mais exigido pelos cultivos agrícolas sendo o cloreto de potássio a fonte mais utilizada. No entanto, esse fertilizante não é recomendado para diversas culturas devido ao seu alto teor de cloro promover perdas na qualidade do produto final, sendo substituído pelo sulfato de potássio. Objetivouse neste trabalho avaliar a produção, os teores de macronutrientes, de óleos essenciais e de linalol em frutos de coentro submetidos a diferentes fontes e doses de potássio. O experimento foi realizado em casa de vegetação, em caixas de plásticos com capacidade de $46 \mathrm{~kg}$, tendo uma mistura de solo com areia como substrato. O delineamento experimental foi de blocos ao acaso, em arranjo fatorial $2 \times 4$, sendo duas fontes de potássio (cloreto e sulfato de potássio) e quatro doses $(50,100,150$ e $200 \mathrm{mg}$ de $\mathrm{K} / \mathrm{kg}$ de substrato), com quatro repetições. As maiores produtividades de frutos, teor de fósforo e de enxofre nos frutos foram obtidos em plantas adubadas com $\mathrm{K}_{2} \mathrm{SO}_{4}$. A aplicação de doses crescentes de potássio, independente da fonte, resultou em aumento no teor de $\mathrm{K}$, decréscimo nos teores de $\mathrm{Ca}$ e não afetou os teores de $\mathrm{Ne} \mathrm{Mg}$ nos frutos. A maior concentração de óleos essenciais nos frutos $(0,15 \mathrm{~g})$ e linalol nos óleos essenciais $(0,42 \mathrm{mg})$, foram obtidas quando se aplicou, respectivamente, 153,8 e 131,3 mg de K/ $\mathrm{kg}$ de substrato, utilizando-se $\mathrm{K}_{2} \mathrm{SO}_{4}$.

Palavras-chaves: Coriandrum sativum, nutrientes, metabolismo secundário, linalol.

Received on January 20, 2020; accepted on June 29, 2020

$\mathrm{C}$ oriander (Coriandrum sativum), belonging to the Apiaceae family, is originally from the Mediterranean region and has been extensively cultivated in North Africa, Central Europe and Asia for more than three thousand years (Sahib et al., 2013; Laribi et al., 2015). Its fruits are widely used as condiments in typical dishes of several countries, such in the Mediterranean region and India (Laribi et al., 2015).
In Brazil, its production area is mainly concentrated in the North and Northeast and is generally managed by family farmers. In the state of Rio de Janeiro, Emater informs that 3,540 tons of fresh coriander were produced in 2019, with an average productivity of $16.8 \mathrm{t} / \mathrm{ha} /$ year (Emater, 2020).

Essential oils extracted from $C$. sativum fruits have as main constituent linalool, a monoterpene displaying antioxidant (Baghdadi et al., 2016; Duarte et al., 2016), antimicrobial and anti-inflammatory (Sourmaghi et al., 2015; Özkinali et al., 2017) activities, as well as insecticide properties (Benelli et al., 2013). Linalool is also an important substance for the production of cosmetics and fragrance products, widely used in the food industry (Duarte et al., 2016).

Due to the importance of essential oils, studies that aim to develop techniques 
that can increase their production and quality are indispensable. It is known that the composition and yield of essential oils can be affected by genetic, physiological and edaphoclimatic variations, with mineral nutrition being an important factor (El Gendy et al., 2015; Chrysargyris et al., 2017ab).

Among mineral nutrients, $\mathrm{K}$ is most required by crops, and its availability depends mainly on soil reserves and fertilizer applications (Zörb et al., 2014). Although not a constituent of any organic compound, this nutrient participates in enzymatic activation, the establishment of turgor and maintenance of cellular electroneutrality, and is involved in photosynthesis, carbohydrate transport, protein synthesis, cell expansion and stomatal movement, considered a quality-linked element (Nieves-Cordones et al., 2016). The most commonly applied $\mathrm{K}$ fertilizer is potassium chloride, which contains on average $60 \%$ water-soluble $\mathrm{K}_{2} \mathrm{O}$. However, its high chlorine content causes losses in the final product quality and, thus, this compound is not recommended for use in certain crops, such as potato and tobacco, being replaced by $\mathrm{K}_{2} \mathrm{SO}_{4}$ (Zörb et al., 2014). $\mathrm{K}_{2} \mathrm{SO}_{4}$, may be more appropriate for essential oil production, as it contains sulfur which, besides being a protein component, is a constituent of the acetyl-CoA molecule involved in terpene synthesis (Dubey et al., 2003).

According to Chrysargyris et al. (2017a) with Mentha spicata and Khalid (2013), with Calendula officinalis, increases have been reported in the content and quality of essential oils extracted from these plants due to potassium applications. Chrysargyris et al. (2017a) observed that the highest production of fresh matter and essential oils in Mentha spicata cultivation, as well as higher carvone content in the oils, was observed at $325 \mathrm{mg} \mathrm{L}^{-1}$ $\mathrm{K}$ applied in the nutrient solution, compared to $275 \mathrm{mg} \mathrm{L}^{-1}$. Khalid (2013) observed an increase in plant growth, content and composition of Calendula officinalis essential oils, at increasing potassium doses up to $173 \mathrm{~kg} \mathrm{ha}^{-1}$ using $\mathrm{K}_{2} \mathrm{SO}_{4}$ as $\mathrm{K}$ source.

Information on the production and quality of essential oils in plants like coriander fertilized with $\mathrm{K}$ sources and doses are still unknown. Therefore, studies that relate $\mathrm{K}$ fertilization to the production and quality of these plants are required. In this context, the aim of the present study was to evaluate coriander fruit production, macronutrient content and essential oil and linalool content in fruits submitted to different $\mathrm{K}$ sources and doses.

\section{MATERIAL AND METHODS}

The research was performed in a greenhouse at the Research Support Unit of the Northern Fluminense Darcy Ribeiro State University campus, Campos dos Goytacazes, Rio de Janeiro, Brazil $\left(21^{\circ} 19^{\prime} \mathrm{S}, 41^{\circ} 10^{\prime} \mathrm{W}, 14\right.$ $\mathrm{m}$ altitude). During the experiment, the temperatures inside the greenhouse ranged between 19 and $42^{\circ} \mathrm{C}$ and relative humidity, between 37 and $98 \%$.

The trial was performed in a randomized block design, as a $2 \times 4$ factorial scheme, with two potassium sources [potassium chloride $(\mathrm{KCl})$ and potassium sulphate $\left.\left(\mathrm{K}_{2} \mathrm{SO}_{4}\right)\right]$ and four potassium doses $(50,100,150,200 \mathrm{mg}$ $\mathrm{K} / \mathrm{kg}$ of substrate), with four replicates. The experimental unit was a plastic box filled with $46 \mathrm{~kg}$ of a mixture of soil and sand as substrate, containing ten plants.

The mixture of soil and washed sand at a 70:30 (v/v) ratio, respectively, was used as substrate, with the following physico-chemical characteristics: $\mathrm{pH}$ in water, $4.2 ; \mathrm{P}, 4 \mathrm{mg} \mathrm{dm}^{-3} ; \mathrm{K}^{+}, 50 \mathrm{mg}$ $\mathrm{dm}^{-3} ; \mathrm{S}, 37 \mathrm{mg} \mathrm{dm}^{-3} ; \mathrm{Ca}^{2+}, 5.2 \mathrm{mmol}_{\mathrm{c}}$ $\mathrm{dm}^{-3} ; \mathrm{Mg}^{2+}, 4.4 \mathrm{mmol}_{\mathrm{c}} \mathrm{dm}^{-3}, \mathrm{Na}^{+}, 0.90$ $\mathrm{mmol}_{\mathrm{c}} \mathrm{dm}^{-3} ; \mathrm{Al}^{3+}, 3.8 \mathrm{mmol}_{\mathrm{c}} \mathrm{dm}^{-3} ; \mathrm{H}+\mathrm{Al}$, $20.4 \mathrm{mmol}_{\mathrm{c}} \mathrm{dm}^{-3}$; sand, $480 \mathrm{~g} \mathrm{~kg}^{-1}$; silt, $60 \mathrm{~g} \mathrm{~kg}^{-1}$ and clay, $460 \mathrm{~g} \mathrm{~kg}^{-1}$. For soil acidity correction, $33.5 \mathrm{mg}$ of dolomitic lime was applied with $80 \%$ PRNT per $46 \mathrm{~kg}$ box and, after 30 days, $30 \mathrm{mg}$ $\mathrm{dm}^{-3}$ of $\mathrm{P}$ was applied in the form of triple superphosphate alongside the potassium doses. For the treatments, the initial potassium content in the substrate was considered and the necessary dose was added, so that the dose reached the final value for each treatment, except for the $50 \mathrm{mg} \mathrm{kg}^{-1} \mathrm{~K}$ treatment, where no potassium source addition was necessary. The soil was subsequently incubated for 10 days.

The coriander cv. Verdão seeds were sown directly in the boxes and, after the appearance of the first pair of leaves, $20 \mathrm{mg} \mathrm{kg}^{-1} \mathrm{~N}$ in the form of urea was applied. During the experiments, daily watering with deionized water was carried out to maintain soil moisture.

At 80 days after sowing, the mature fruits (Msaada et al., 2007) were collected and evaluated regarding number of fruits, fresh fruit mass, dry fruit mass and macronutrients content, as well as essential oil content in fruits and linalool levels in essential oils.

To evaluate nutrient content, the fruits were dried at $65^{\circ} \mathrm{C}$ in a forced ventilation oven for 72 hours and then ground in a Willey-type knife mill. For $\mathrm{N}$ content determinations the plant material was submitted to a sulfur digestion and $\mathrm{N}$ was determined by the Nessler method (Jackson, 1965) and the other macronutrients contents were determined using plasma spectrometry (ICPE-9000, Shimadzu, Kyoto, Japan) after digestion with $\mathrm{HNO}_{3}$ and $\mathrm{H}_{2} \mathrm{O}_{2}$, in an open digestion system. ICPE-9000 conditions were $8.0 \mathrm{~L} \mathrm{~min}^{-1}$ plasma gas, $0.70 \mathrm{~L} \mathrm{~min}^{-1}$ auxiliary gas and $0.55 \mathrm{~L}$ min $^{-1}$ carrier gas (Peters, 2005).

Essential oils were extracted by hydrodistillation by steam stripping in a Clevenger-type apparatus for two hours using $50 \mathrm{~g}$ of fresh fruits (Msaada et al., 2007). Following extraction, essential oils were collected using Pasteur pipettes and their mass was used to determine essential oil content, calculated by the formula:

$$
\begin{gathered}
\text { Essential oil content }(\%)=\mid \\
\left(\frac{\text { mass of the extracted essential oil }}{\text { plant mass used }}\right) \times 100
\end{gathered}
$$

The chemical analysis of the essential oils was carried out using a Gas Phase Chromatograph coupled to a Mass Spectrometer (Shimatzu 17A). The samples were diluted in hexane and then subjected to gas chromatography as follows: using a DB5 $30 \mathrm{~m}$ capillary column with $0.25 \mathrm{~mm}$ internal diameter, $220^{\circ} \mathrm{C}$ temperature in the injector and $240^{\circ} \mathrm{C}$ in the detector, initial temperature of $60^{\circ} \mathrm{C}$, maintained for one minute, increasing at $3^{\circ} \mathrm{C}$ per minute, up to 
$240^{\circ} \mathrm{C}$, which was maintained for another 30 minutes, at a 1:20 split ratio (Msaada et al., 2007).

The data were submitted to analysis of variance. For the quantitative factor, a polynomial regression analysis, an $\mathrm{F}$ test of the regression variance analysis and the coefficient of the statistically significant model and higher $\mathrm{R}^{2}$ were used, while the Tukey test $(\mathrm{p}<0.05)$ was performed on the qualitative factor.

\section{RESULTS AND DISCUSSION}

Interactions between $\mathrm{K}$ doses and sources for number of fruits, fresh fruit mass, essential oil content, linalool oil content and $\mathrm{S}$ and $\mathrm{P}$ content in $C$. sativum fruits (Figures 1A, 1B, 2A, 2B, $3 \mathrm{~B}$ and $4 \mathrm{~A}$ ) were observed. $\mathrm{K}$ and $\mathrm{Ca}$ levels in the fruits were influenced by potassium doses (Figures $3 \mathrm{~A}$ and $4 \mathrm{~B}$ ). $\mathrm{N}$ and $\mathrm{Mg}$ contents were not influenced $(\mathrm{p} \leq 0.05)$ by $\mathrm{K}$ sources and doses in coriander fruits, with mean content of $28.1 \mathrm{~g} \mathrm{~kg}^{-1}$ and $4.18 \mathrm{~g} \mathrm{~kg}^{-1}$, respectively.

In the present study, higher $\mathrm{K}$ supplies resulted in increased fruit production (Figures 1A and 1B) and nutrient content in coriander fruits (Figure 3A). El-Bassiony et al. (2010) and Afzal et al. (2015), investigating sweet pepper and tomato plants, verified positive effects of $\mathrm{K}$ application on harvested fruit yield and quality.

The highest fruit yields were obtained at $146.2 \mathrm{mg} \mathrm{K} \mathrm{kg}^{-1}$ substrate $\mathrm{K}_{2} \mathrm{SO}_{4}$ used and $126.2 \mathrm{mg} \mathrm{K} \mathrm{kg}^{-1}$ substrate $\mathrm{KCl}$ used, with $41 \%$ increase in the number of coriander fruits when fertilized with $\mathrm{K}_{2} \mathrm{SO}_{4}$ (Figure 1A). The highest fresh matter masses were estimated at 140.6 mg K kg-1 substrate $\mathrm{K}_{2} \mathrm{SO}_{4}$ and 143.7 $\mathrm{mg} \mathrm{K} \mathrm{kg}{ }^{-1}$ substrate $\mathrm{KCl}$ used, with $27 \%$ increase observed when potassium sulphate was applied (Figure 1B).

Potassium participates in important plant metabolism processes, such as sugar and water transport, protein and starch synthesis and stomatal opening and closing, as well as in the activation of enzymes involved in the photosynthetic process, such as pyruvate kinase and phosphoenolpyruvate (Prajapati \& Modi, 2012; Nieves-Cordones et al., 2016). Potassium has been the target of some researchers mainly because it is essential for enzyme activation such as enzyme of essential oil (Khalid, 2013).

However, $\mathrm{KCl}$ as the $\mathrm{K}$ source led to lower fruit production and fresh fruit mass values compared to $\mathrm{K}_{2} \mathrm{SO}_{4}$ (Figures $1 \mathrm{~A}$ and $1 \mathrm{~B}$ ). This may be related to the presence of $\mathrm{S}$, since the contents of this nutrient were higher in plants fertilized with the sulfate (Figure $4 \mathrm{~A}) . \mathrm{S}$ is an essential mineral nutrient for plants, is found in amino acids such as cysteine and methionine, proteins (Marschner, 2012) and as acetyl-CoA molecule component that is involved in the synthesis of terpenes (Dubey et al., 2003).
In this context, one study evaluated the effects of $\mathrm{K}_{2} \mathrm{SO}_{4}$ and $\mathrm{KCl}$ on Tagetes erecta flower production and plant growth, and the highest values for these variables were obtained for the highest $\mathrm{K}$ dose (240 kg K $2 \mathrm{O} \mathrm{ha}^{-1}$ ) using $\mathrm{K}_{2} \mathrm{SO}_{4}$ as source (Sanghamitra et al., 2015). Similar results were observed in the cultivation of foraging species by testing different $\mathrm{K}$ sources and doses, where the highest growth was observed at the highest $\mathrm{K}_{2} \mathrm{SO}_{4}$ dose (Sima et al., 2013).

Although $\mathrm{Cl}$ is considered an essential plant micronutrient, required in small amounts, when present in high concentrations, it can result in negative effects both on the growth and quality of the harvested product, depending on the plant species (Marshner, 2012; Geilfus, 2018). Thus, despite being a highly recommended source of $\mathrm{K}$, mainly due to the market price, $\mathrm{KCl}$ can be detrimental to the production quality of certain crops, such as persimmon, tobacco, potatoes and wheat, among others. According to Geilfus (2018), excess $\mathrm{Cl}$ induces dysfunctions that hinder crop quality and impair starch partitioning, nutrient absorption, protein biosynthesis and photosynthesis. Thus, it is often suggested that $\mathrm{KCl}$ could be replaced by $\mathrm{K}_{2} \mathrm{SO}_{4}$ in crops (Khan et al., 2014).

The essential oil ( $0.15 \mathrm{~g})$ and linalool $(0.43 \mathrm{mg})$ content in the fruits increased when applying $\mathrm{K}_{2} \mathrm{SO}_{4}$, with the highest value detected at the estimated dose of

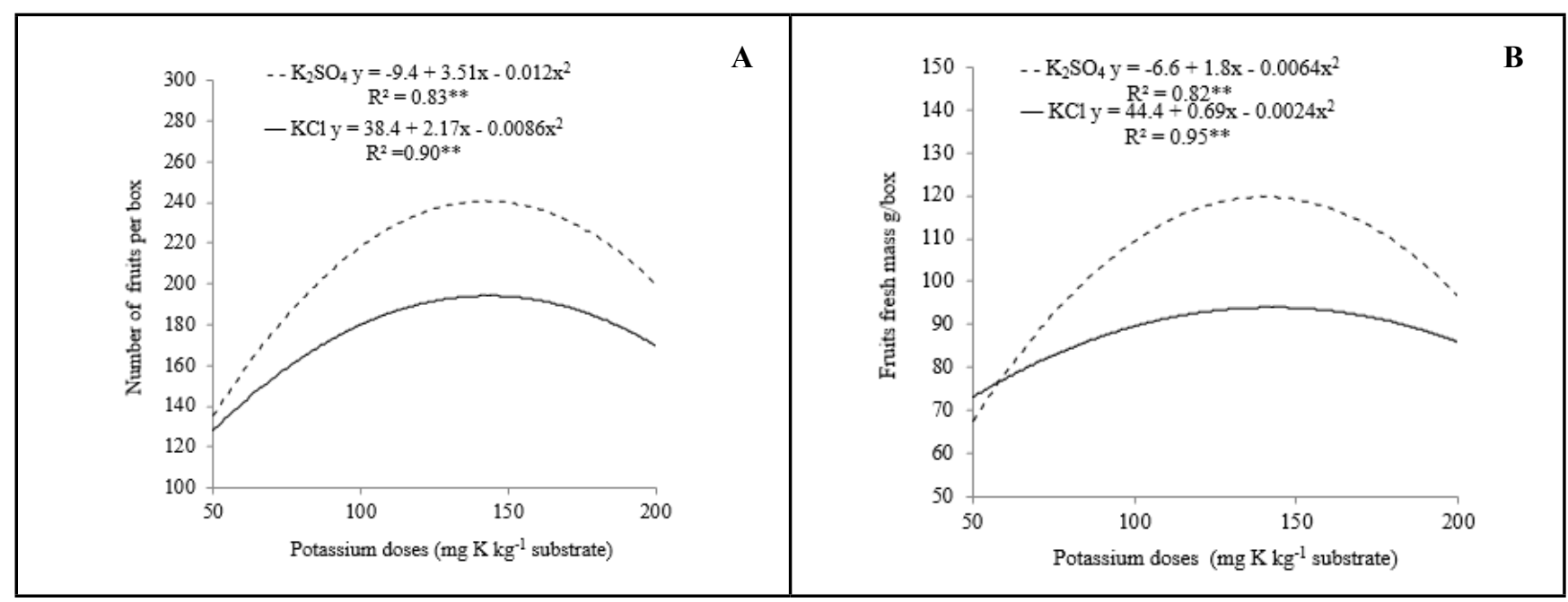

Figure 1. Total coriander fruits per box (A) and fresh fruits mass per box (B) grown under different potassium sources and doses. Campos dos Goytacazes, UENF, 2014. 

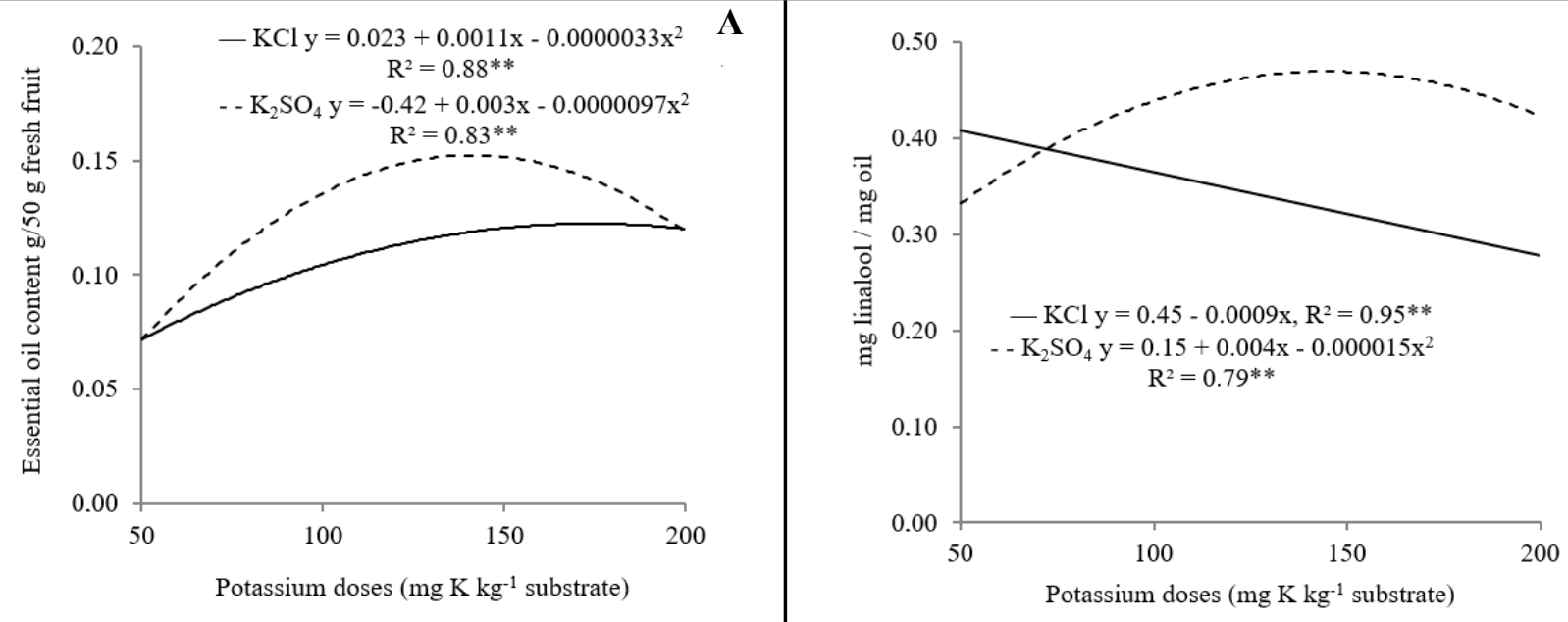

Figure 2. Essential fresh fruits oil content (A) Essential fruit oil linalool content (B) of coriander grown under different potassium sources and doses. Campos dos Goytacazes, UENF, 2014.
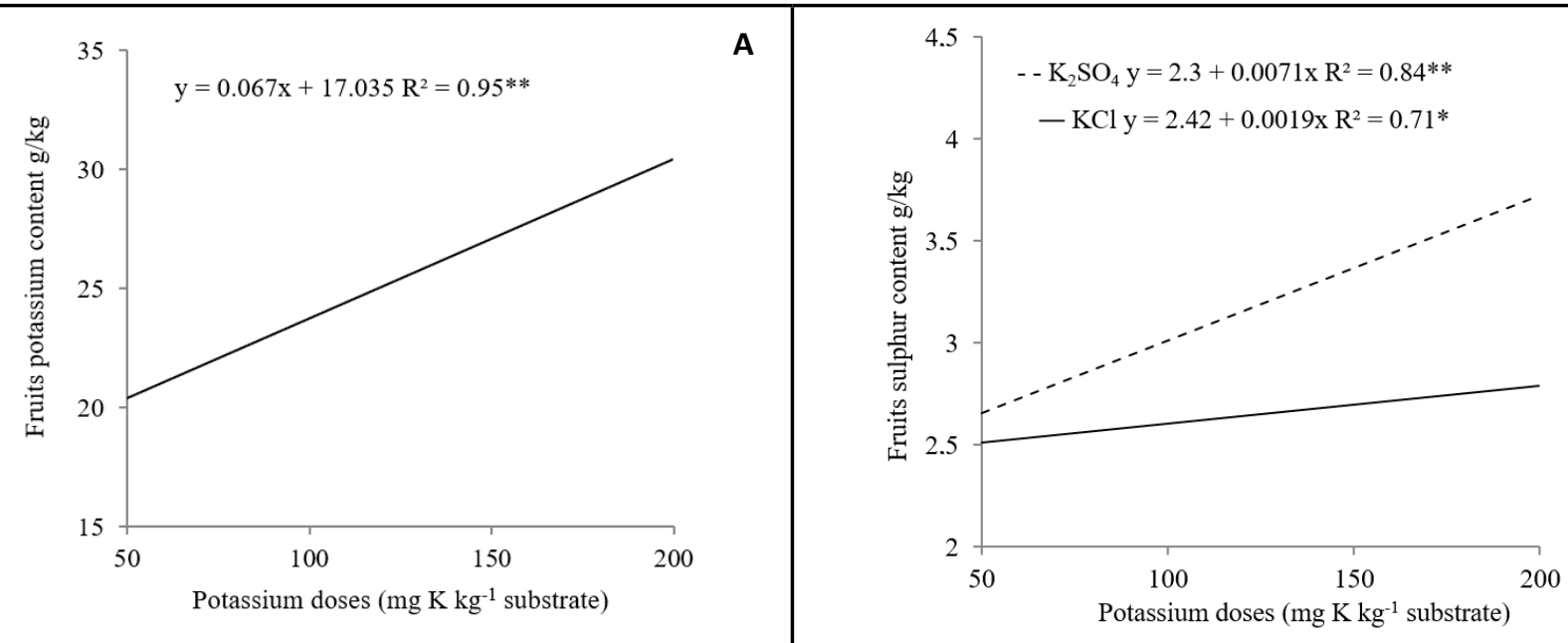

Figure 3. Potassium (A) and sulphur (B) coriander fruit content grown under different potassium sources and doses. Campos dos Goytacazes, UENF, 2014.

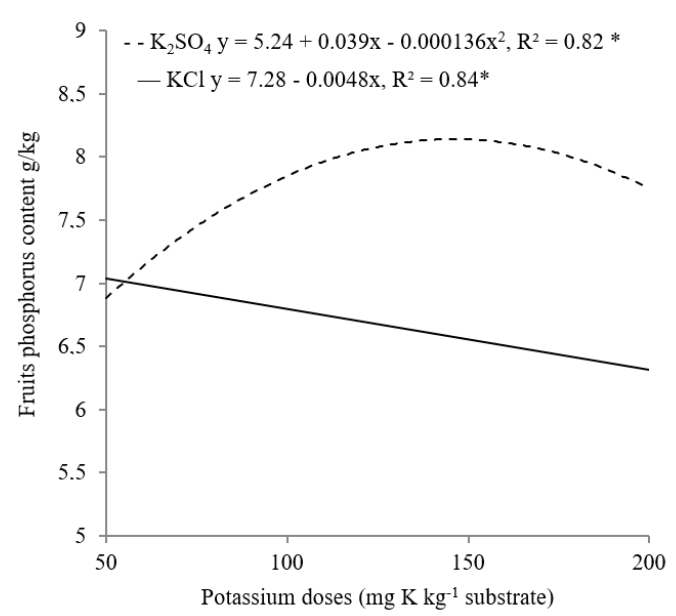

A

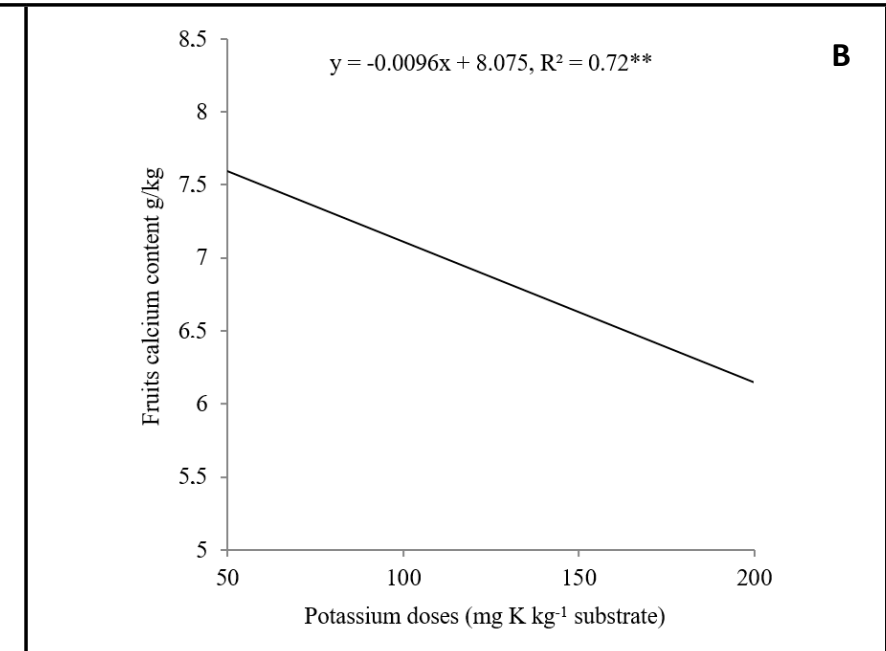

Figure 4. Phosphorus (A) and calcium (B) content in coriander fruits grown under different potassium sources and doses. Campos dos Goytacazes, UENF, 2014. 
153.8 and $131.3 \mathrm{mg} \mathrm{K} \mathrm{kg}^{-1}$ substrate, respectively (Figure $2 \mathrm{~A}$ and $2 \mathrm{~B}$ ), contrary to what was observed on $\mathrm{KCl}$ doses, linear decrease for the linalool present in the oils extracted from $C$. sativum fruits was observed.

Essential oil production can be influenced by both the source and the amount of nutrients applied (El Gendy et al., 2015; Chrysargyris et al., 2017a). Increasing $\mathrm{K}$ doses in coriander cultivation resulted in higher essential oil production (Figure 2A). The same was observed for Lavandula angustifolia, where increased $\mathrm{K}$ content in the nutrient solution, from 275 $\mathrm{mg} \mathrm{L}^{-1}$ to $300 \mathrm{mg} \mathrm{L}^{-1}$, led to higher oil production (Chrysargyris et al., 2017b). Khalid (2013), assessing K doses $\left(\mathrm{K}_{2} \mathrm{SO}_{4}\right)$ in Calendula officinalis, reported that the highest essential oil accumulation $(0.29 \%$ and $0.095 \mathrm{~g}$ plant $^{-1}$ ) was observed at a $\mathrm{K}$ treatment of $173.2 \mathrm{~kg} \mathrm{ha}^{-1}$ compared to the control treatment $\left(0.13 \%\right.$ and $\left.0.015 \mathrm{~g} \mathrm{plant}^{-1}\right)$.

The higher oil production observed in coriander fruits fertilized with $\mathrm{K}_{2} \mathrm{SO}_{4}$ (Figure 2A) can also be linked to increased $\mathrm{S}$ (Figure $3 \mathrm{~B}$ ) and $\mathrm{P}$ contents (Figures 4A) when using the same $\mathrm{K}$ source. Increments in $\mathrm{S}$ and $\mathrm{P}$ levels in the coriander seeds of $40 \%$ and $17.3 \%$, respectively were observed when comparing the lowest and highest $\mathrm{K}_{2} \mathrm{SO}_{4}$ doses. The effect of $\mathrm{S}$ on essential oil production has also been observed in Cymbopogon martinii, where plants grown at $40 \mathrm{~kg} \mathrm{ha}^{-1} \mathrm{~S}$ presented higher essential oil yields compared to plants cultivated without fertilization (Rao et al., 2015). Hani et al. (2015), found that coriander plants fertilized with $24 \mathrm{~kg} \mathrm{P}$ per hectare increased essential seed oil content by $16 \%$ when compared to nonfertilized plants.

C. sativum essential oils consist of monoterpenes, including linalool. Geranyl diphosphate (GPP, $\mathrm{C}_{10}$ ) is the universal precursor in monoterpene synthesis and is synthesized from the fusion of isopentenyl diphosphate (IPP, $\mathrm{C}_{5}$ ) with its isomer, dimethyl diphosphate (DMAPP, $\mathrm{C}_{5}$ ). ATP, NADPH and acetylCoA molecules are required for IPP and DMAPP synthesis. Thus, essential oil biosynthesis is dependent on $\mathrm{S}$ and $\mathrm{P}$, since these nutrients are a constituent part of these molecules (Dubey et al., 2003). Freitas et al. (2004), studying phosphate fertilization in Mentha arvensis, verified that increased $\mathrm{P}$ doses from zero to $50 \mathrm{mg}$ per $\mathrm{kg}$ of soil resulted in a $74 \%$ increase in essential oil concentrations.

In addition to essential oil content, essential oil composition is also affected by mineral nutrients. In the present study, linalool levels in fruits and oils were higher with increasing $\mathrm{K}$ doses (Figures 2B and 3A), which may be due to both the increase of fruit $\mathrm{K}$ content (Figure $3 \mathrm{~B}$ ) and $\mathrm{S}$ and $\mathrm{P}$ contents (Figures 4A and 4B). In this context, one study reported that the proportion of essential constituents of C. officinalis essential oils ( $\alpha$-cadinol, $\beta$-cadinene and $\alpha$-cadinene) was altered by $\mathrm{K}$ doses (Khalid, 2013). In another study, increasing $\mathrm{K}$ concentrations in Mentha $x$ gracilis nutrient solution increased myrcene, $\alpha$-pinene, $\beta$-pinene and limonene productions and decreased linalool and pulegone levels (Garlet et al., 2013).

The higher $\mathrm{P}$ and $\mathrm{S}$ contents in coriander fruits of plants fertilized with $\mathrm{K}_{2} \mathrm{SO}_{4}$ led to higher linalool levels in comparison to plants fertilized with $\mathrm{KCl}$ (Figure 2B and 3A). Some studies highlight the important role of $\mathrm{S}$ and $\mathrm{P}$ in isoprenoid synthesis, since they are a part of several molecules that participate in this process, such as acetylCoA, ATP and NADPH (Dubey et al., 2003). P effects on linalool synthesis in coriander fruits was also observed by Hani et al. (2015), where increasing doses of this nutrient led to increased linalool levels. In another study, the highest $\mathrm{S}$ dose in C. martinii cultivation increased cis$\beta$-ocimene, linalool, geraniol, geranyl acetate and geranyl hexanoate levels in oils (Rao et al., 2015), and S increasing doses in the cultivation of Cymbopogon flexuosus reduced citral content in essential oils (Zheljazkov et al., 2011).

As predicted, increasing $\mathrm{K}$ doses led to increased nutrient content in fruits (Figure 3A). On the other hand, $\mathrm{Ca}$ content was reduced (Figure 4B). $\mathrm{Ca}$ is absorbed by un-suberized root system cells, in the form of $\mathrm{Ca}^{2+}$, and the increase of other salts, such as $\mathrm{K}^{+}$, can decrease $\mathrm{Ca}$ absorption by the roots
(Marschner, 2012).

An increase in $\mathrm{S}$ and $\mathrm{P}$ contents in coriander fruits (Figures 4A and 4B) was observed with increasing $\mathrm{K}$ doses in the form of $\mathrm{K}_{2} \mathrm{SO}_{4}$. The use of $\mathrm{K}_{2} \mathrm{SO}_{4}$ source elevated $\mathrm{P}$ content up to the estimated dose of $143.4 \mathrm{~K} \mathrm{mg}$ $\mathrm{kg}^{-1}$ of substrate (Figure 4A). During amino acid synthesis, the reduction of $\mathrm{S}$ requires considerable amounts of energy, which may explain the increased $P$ absorption observed herein, since this nutrient plays a fundamental role in energy transfer in plant metabolism. On the other hand, plants fertilized with $\mathrm{KCl}$ presented decreased $\mathrm{P}$ contents (Figure 4B). Because this is a nutrient only necessary in small amounts, $\mathrm{Cl}$ in excess in the root environment can cause toxicity, due to increased salinity, which then decreases $P$ concentrations in plant tissue, due to decreased phosphate activity in the soil solution (Geilfus, 2018).

The highest fruit yields and phosphorus and sulfur contents were observed in coriander plants fertilized with potassium sulfate. Essential oil contents in fruits increased when applying $\mathrm{K}_{2} \mathrm{SO}_{4}$, with the highest value obtained at an estimated dose of 153.8 $\mathrm{mg} \mathrm{kg}^{-1} \mathrm{~K}$, while for linalool this was estimated at $131.3 \mathrm{mg} \mathrm{kg}^{-1} \mathrm{~K}$. Thus, $\mathrm{K}_{2} \mathrm{SO}_{4}$ application increases the number, fresh mass and essential oil content of coriander fruits.

\section{ACKNOWLEDGMENTS}

This research was supported by the FAPERJ (Fundação Carlos Chagas Filho de Amparo à Pesquisa do Estado do Rio de Janeiro) <www.faperj.br>.

\section{REFERENCES}

AFZAL, I; HUSSAIN, B; BASRA, SMA; ULLAH, SH; SHAKEEL, Q; KAMRAN, M. 2015. Foliar application of potassium improves fruit quality and yield of tomato plants. Acta Scientiarum Polonorum Hortorum Cultus 14: 3-13.

BAGHDADI, HH; EL-DEMERDASH, FM; RADWAN, EH; HUSSEIN, S. 2016. The protective effect of Coriandrum sativum L. oil against liver toxicity induced by Ibuprofein in rats. Journal of Bioscience and Applied Research 2: 197-202. 
BENELLI, G; FLAMINI, G; FIORE, G; CIONI, PL; CONTI, B. 2013. Larvicidal and repellent activity of the essential oil of Coriandrum sativum L. (Apiaceae) fruits against the filariasis vector Aedes albopictus Skuse (Diptera:Culicidae). Parasitology Research 112: 1155-1161.

CHRYSARGYRIS, A; XYLIA, P; BOTSARIS, G; TZORTZAKIS, N. 2017a. Antioxidant and antibacterial activities, mineral and essential oil composition of spearmint (Mentha spicata L.) affected by the potassium levels. Industrial Crop and Products 103: 202-212.

CHRYSARGYRIS, A; DROUZA，C; TZORTZAKIS, N. 2017b. Optimization of potassium fertilization/nutrition for growth, physiological development, essential oil composition and antioxidant activity of Lavandula angustifolia Mill. Journal of Soil Science and Plant Nutrition 17: 291-306.

DUARTE, A; LUÍS, A; OLEASTRO, M; DOMINGUES, FC. 2016. Antioxidant properties of coriander essential oil and linalool and their potential to control Campylobacter spp. Food Control 61: 115-122.

DUBEY, VS; BHALLA, R; LUTHRA, R. 2003. An overview of the non-mevalonate pathway for terpenoid biosynthesis in plants. Journal Bioscience 28:637-646.

EL-BASSIONY, AM; FAWZY, ZF; ABD ELSAMAD, EH; RIAD, GS. 2010. Growth, yield and fruit quality of sweet pepper plants (Capsicum annuum L.) as affect by potassium fertilization. Journal of American Science 6: 722-729.

EL GENDY, AG; EL GOHARY, AE; OMER, EA; HENDAWY, SF; HUSSEIN, MS; PETROVA, V; STANCHEVA, I. 2015. Effect of nitrogen and potassium fertilizer on herbage and oil yield of chervil plant (Anthriscus cerefolium L.). Industrial Crop and Products 69: 167-174.

EMATER. 2020. Relatório por culturas do sistema aspa/agrogeo-ano 2019. Available at http:// www.emater.rj.gov.br/images/cul2019.htm. Accessed April 27, 2020.

FREITAS, MSM; MARTINS, MA; VIEIRA, IJC. 2004. Produção e qualidade de óleos essenciais de Mentha arvensis em resposta à inoculação de fungos micorrízicos arbusculares. Pesquisa Agropecuária Brasileira 39: 887-894.

GARLET, TMB; PAULUS, D; FLORES, R.
2013. Production and chemical composition of Mentha x piperita var. citrate (Ehrh.) Briq. essential oil regarding to different potassium concentrations in the hydroponic solution. Journal of Biotechnology and Biodiversity. 4: 200-206.

GEILFUS, CM. 2018. Review on the significance of chlorine for crop yield and quality. Plant Science. 270: 114-122

HANI, MM; HUSSEIN, SAHA; MURSY, MH; NGEZIMANA, W; MUDAU, FN. 2015. Yield and essential oil response in coriander to water stress and phosphorus fertilizer application. Journal of Essential Oil Bearing Plants. 18: 82-92.

JACKSON, ML. 1965. Soil chemical analysis. New Jersey: Prentice-Hall.

KHALID, AK. 2013. Effect of potassium uptake on the composition of essential oil content in Calendula officinalis L. flowers. Emirates Journal Food and Agriculture 25: 189-195.

KHAN, SA; MULVANEY, RL; ELLSWORTH, TR. 2014. The potassium paradox: Implications for soil fertility, crop production and human health. Renewable Agriculture and Food Systems. 29: 3-27.

LARIBI, B; KOUKI, K; M'HAMDI, M; BETTAIEB, T. 2015. Coriander (Coriandrum sativum L.) and its bioactive constituents. Fitoterapia 103: 9-26.

MARSCHNER, P. 2012. Functions of macronutrients. In: Mineral nutrition of higher plants, (ed) P. Marschner. $3^{\text {rd }}$ ed. Elsevier Ltd.

MSAADA, K; HOSNI, K; TAARIT, MB; CHAHED, T; KCHOUK, ME; MARZOUK, B. 2007. Changes on essential oil composition of coriander (Coriandrum sativum L.) fruits during three stages of maturity. Food Chemistry. 102: 1131-1134.

NIEVES-CORDONES, M; SHIBLAWI, FR; SENTENAC, H. 2016. Roles and transport of sodium and potassium in plants. In: The alkali metal ions: Their role for life, (eds) A. SIGEL, H. SIGEL, R. SIGEL. Springer, Cham. p.291-324.

ÖZKINALI, S; ŞENER, N; GUR, M; GUNEY, K; OLGUN, Ç. 2017. Antimicrobial activity and chemical composition of coriander \& galangal essential oil. Indian Journal Pharmaceutical Education 51: 221-223.
PETERS, JB. 2005. Wisconsin procedures for soil testing, plant analysis and feed \& forage analysis: Plant analysis. Department of Soil Science, College of Agriculture and Life Sciences, University of Wisconsin-Extension, Madison, WI.

PRAJAPATI, K; MODI, HA. 2012. The importance of potassium in plant growth - A review. Indian Journal of Plant Sciences 1: 177-186.

RAO, BRR; RAJPUT, DK; PATEL, RP. 2015. Improving yield and quality of palmarosa [Cymbopogon martini (Roxb.) Wats. var. Motia Burk.] with sulfur fertilization. Journal of Plant Nutrition 38: 384-396.

SAHIB, NG; ANWAR, F; GILANI, A; HAMID, AA; SAARI, N; ALKHARFY, KM. 2013. Coriander (Coriandrum sativum L.): A potential source of high-value components for functional foods and nutraceuticals - A review. Phytotherapy Research 27: 1439-1456.

SANGHAMITRA, M; BHASKAR, VV; RAO, AVDD; SUBBARAMAMMA, P. 2015. Effect of different sources and levels of potassium on yield and carotenoids content of African Marigold (Tagetes erecta Linn.) cv. "Maxima Yellow". Plant Archives 15: 633-636.

SIMA, NAKK; AHMAD, ST; PESSARAKLI, M. 2013.Comparative study of different salts (sodium chloride, sodium sulfate, potassium chloride, and potassium sulfate) on growth of forage species. Journal of Plant Nutrition 36: 214-230.

SOURMAGHI, MHS; KIAEE, G; GOLFAKHRABADI, F; JAMALIFAR, H; KHANAVI, M. 2015. Comparison of essential oil composition and antimicrobial activity of Coriandrum sativum L. extracted by hydrodistillation and microwave-assisted hydrodistillation. Journal of Food Science and Technology 52: 2452-2457.

ZHELJAZKOV, VD; CANTRELL, CL; ASTAKIE, T; CANNON, JB. 2011. Lemongrass productivity, oil content and composition as a function of nitrogen, sulphur and harvest time. Agronomy Journal 103: 805-812.

ZÖRB, C; SENBAYRAM, M; PEITER, E. 2014. Potassium in agriculture - Status and perspectives. Journal of Plant Physiology 171: 656-669. 